\title{
EFFECT OF ADRENALINE ON GLUCOSE UPTAKE BY THE CANINE LARGE BOWEL
}

\author{
ALADA A.R.A, FAGBOHUN, T. D. AND OYEBOLA D. D. 0. \\ Department of Physiology, College of Medicine, University of Ibadan, Ibadan - Nigeria.
}

\begin{abstract}
The effect of adrenaline on the glucose uptake by the large intestine was studied on a fasted, anaesthetized dog. A vein draining a segment of the colon was cannulated for blood flow measurement and blood samples were obtained for measurement of glucose content of the arterial and venous blood from the colonic segment. Glucose uptake was calculated as the product of colonic blood flow and arterio-venous glucose difference $\{(A-V)$ glucose $\}$. When adrenaline $(5 \mu \mathrm{g} / \mathrm{kg})$ was injected, glucose uptake by the colon increased by about $150 \%$. This increase is much less than increases of $400 \%$ and $700 \%$ observed in upper jejunium and terminal ileum respectively in previous studies. However, the resting glucose uptake of $(28.28 \pm 20 \mathrm{mg} / \mathrm{min})$ of the colon is higher than that of the small intestine $(17.77 \pm 1.56 \mathrm{mg} / \mathrm{min})$. We suggest from our studies that lower glucose uptake in the colon may well indicate a lower metabolic activity in the colon. From the results we concluded that the colon is involved in glucose homeostasis and that the colonic increase in glucose uptake in response to adrenaline is mediated by alpha and beta adrenergic receptors.
\end{abstract}

KEYWORDS: :Adrenaline, glucose uptake, colon, dog, adrenergic receptors.

\section{INTRODUCTION}

Previous studies (Alvarez and Stark, 1918; Evans, 1923; Dickens and Weilmalherbe, 1941) have shown that the metabolism of the intestine in dogs, rabbits, cats guinea pig, sheep, rat and mouse declined from the proximal to the distal end of the intestine. It is not known whether this proximo-distal gradient in metabolic activities of the different animals is in any way related to glucose uptake. Simultaneous measurements of glucose uptake and oxygen consumption have shown that the glucose taken up by the small intestine is far in excess of what can be accounted for on the basis of oxidative metabolism (Durotoye and Grayson, 1971; Grayson and Oyebola, 1983; 1985).

The reports of Alada and Oyebola $(1996 ; 1997)$ have provided strong evidence that the gastrointestinal tract (G.I.T.) plays a modulatory role in glucose homeostasis. Thus, the g.i.t. will increase its glucose uptake during hyperglycemia and release glucose into circulation during hypoglycemia.

Studies on glucose uptake of the g.i.t. in dog have been confined mainly to the duodenum, upper jejunum (Durotoye and Grayson, 1971; Grayson and Oyebola; 1983; 1985; Alada and Oyebola, 1996; 1997) and the terminal ileum (Oyebola and Durosaiye, 1988). There has been no study on glucose uptake in the dog large intestine. The role of the canine large bowel (if any) in glucose homoeostasis is therefore unknown. The pertinent question is, does the large intestine increase its glucose uptake during hyperglycemia as occurred in the small intestine.? Secondly, is the large bowel involved in glucose homeostasis. The need to provide answers to these questions is the basis for this study?

\section{MATERIALS AND METHODS}

Male mongrel dogs weighing $8-13 \mathrm{~kg}$ were used for the study. Each animal was fasted for $18-24 \mathrm{~h}$ before the start of an experiment; but they were allowed free access to drinking water. Anaesthesia was induced by intravenous sodium pentobarbitone $30 \mathrm{mg} / \mathrm{kg}$. Light anaesthesia was maintained with supplemental doses of i.v. pentobarbital sodium. The trachea was intubated using a Y-piece cannula and the animal was allowed to breathe room air (Temp. $25^{\circ} \mathrm{C}$ ) spontaneously. Respiration was assisted by a stand by respiratory pump (Palmer, England) whenever necessary. Cannulae were placed in the right femoral vein and right femoral artery.

Through a midline laporotomy, a part of the ascending colon of the large intestine was identified and a vein draining a segment of this colon (right colonic vein) was cannulated using $1.8 \mathrm{~mm}$ (i.d.) polyethylene tubing (P.E 260). The right colonic vein cannula was moved into an extra-corporeal position and a noncrushing clamp was applied to its free end. In order to maintain the fluidity of blood, all animals were heparinized with sodium heparin, 300 units per $\mathrm{kg}$ intravenously. The abdomen was closed in two layers with interrupted sutures.

After all surgical procedures were completed, a 60 minutes stabilization period was allowed in all animals. After stabilization, basal measurement of colonic venous blood flow and collection of arterial and venous blood samples for glucose estimation from femoral artery and colonic venous cannulae respectively were made at $5 \mathrm{~min}$ intervals over $15 \mathrm{~min}$. the mean was taken as the control,. The blood flow was determined by timed collection as previously described (Alada and Oyebola, 1996).

\section{Experimental Procedures}

The experiments were carried out on the following four groups of dogs.

Untreated Group (Group l): After the basal measurements, a bolus injection of adrenaline $(5 \mathrm{ug} / \mathrm{kg})$ was given intravenously. Five dogs were used for the dose of adrenaline administered. Thereafter, venous blood flow, arterial and venous blood glucose levels were monitored at intervals for $90 \mathrm{~min}$ during the postinjection observation period.

Pretreatment With a Adrenergic Blocker (Group II): Five dogs were studied. Each animal was given i.v. injection 
of prazosin, $0.2 \mathrm{mg} / \mathrm{kg}$. Forty minutes was allowed for the drug to take effect. Then basal recording of venous blood flow and sample collection for resting arterial and venous blood glucose were made. After the basal recording and blood sample collection, adrenaline, $5 \mathrm{ug} / \mathrm{kg}$ was given i.v. as a bolus injection. The blood flow and arterial and venous blood glucose levels were monitored for 90 minutes as in group I.

\section{Pretreatment With B-Adrenergic Blocker (Group lii)}

Five dogs were also studied. Each animal was given i.v. injection of propranolol, $0.5 \mathrm{mg} / \mathrm{kg}$. After forty minutes and basal recording of blood flow and sample collection for resting arterial and venous blood glucose, adrenaline, $5 \mathrm{ug} / \mathrm{kg}$ was given i.v. as a bolus injection. Similar measurement to those in group I were made.

\section{Normal Saline Group (Group IV)}

Another group of five dogs was studied for the effect of normal saline $(0.2 \mathrm{ml} / \mathrm{kg})$ on blood flow, and arterial and venous blood glucose levels as in other groups. This group served as the control.

Blood glucose was determined by the glucose oxidase method as modified by Trinder (1969). Glucose uptake $(\mathrm{Mg} / \mathrm{min})$ was calculated as a product of the arterio-venous glucose difference, (A-V) and colonic blood flow per minute.

All values given are the mean \pm S.E. of the variables measured. Significance was assessed by the student's t-test for two means of independent variables. $P$ values of 0.05 or less were taken as statistically significant.

\section{RESULTS}

\section{Effect of Normal Saline}

Normal saline had no effect on the blood flow, arterial and venous blood glucose levels and colonic glucose uptake. The mean resting blood flow in the colon was $10.1 \pm 0.2 \mathrm{ml} / \mathrm{min}$. The resting colon had a glucose uptake of $28.28 \pm 1.2 \mathrm{mg} / \mathrm{min}$.

\section{Effects Of Adrenaline}

The effect of intravenous injection of adrenaline or arterial and venous blood glucose levels, arterio-venous glucose difference $(A-V)$, colonic venous blood flow and colonic glucose uptake are shown in tables 1 and 2 and figures 1 and 2. Intravenous injection of adrenaline caused an immediate increase in blood glucose levels which reached its peak some fifteen minutes postinjection and thereafter returned to basal levels.

Adrenaline also produced significant increase in (A$\mathrm{V})$ glucose. (Figures 1a and 2a). The (A-V) glucose increased from a basal value of $2.8 \pm 0.01 \mathrm{mg} / \mathrm{dl}$ to a peak value of $6.6+0.03 \mathrm{mg} / \mathrm{fl}$. Intravenous injection of adrenaline also increased the colonic blood flow from $10.1 \pm 0.2 \mathrm{ml} / \mathrm{min}$ to $11.5 \pm 0.3 \mathrm{ml} / \mathrm{min}$. This increase was significant $(P<0.05)$ (figures $1 b$ and $2 b)$.

When the colonic glucose uptake was calculated as the product of $(\mathrm{A}-\mathrm{V})$ glucose and blood flow, adrenaline increased the glucose uptake of large intestine from a basal value $28.28 \pm 1.2 \mathrm{mg} / \mathrm{min}$ to a peak value of 75.90 $\pm 1.4 \mathrm{mg} / \mathrm{min}$ which is an increase of about $150 \%$.

\section{Effects of Alpha Adrenergic Blocker}

The effect of prazosin on arterial and venous blood glucose levels after adrenaline administration is shown in table 1. Prazosin significantly reduced the peaks of adrenaline-induced increases in arterial and venous blood glucose. Prazosin however, did not cause any significant change in the adrenaline-induced increase in blood flow (Figure 1b). Prazosin reduced significantly the adrenaline induced increases in (A-V) glucose and intestinal glucose uptake (Figure 1a and 1c).

\section{Effect of Beta Adrenergic Blockers}

The effect of propranolol on adrenaline induced changes in blood glucose; blood flow and intestinal glucose uptake are shown in table 2 and figure 2. Table 2 shows that propranolol increased the resting blood glucose levels. It also reduced significantly adrenaline induced hyperglycemia. Propranolol also increased the resting $(A-V)$ glucose and intestinal glucose uptake (figure 2a and 2c). Propranolol, however, abolished the adrenaline induced increase in colonic blood flow (figure $2 b)$.

Table 1:

EFFECT OF ADRENALINE (5mg/Kg) ON ARTERIAL AND VENOUS GLUCOSE LEVELS BEFORE AND AFTER ALPHA ADRENERGIC RECEPTOR BLOCKADE $=5\left({ }^{*}-\mathrm{P}<0.05,{ }^{* *}-\mathrm{P}<0.01 ;{ }^{* *}-\mathrm{P}<0.001\right)$

\begin{tabular}{|c|c|c|c|c|c|c|c|c|c|c|c|}
\hline 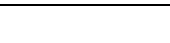 & & 0. $\min$ & $5 \mathrm{~min}$ & $10 \mathrm{~min}$ & $15 \mathrm{~min}$ & $20 \mathrm{~min}$ & $25 \mathrm{~min}$ & 30min & $45 \mathrm{~min}$ & $60 \mathrm{~min}$ & $90 \mathrm{~min}$ \\
\hline $\begin{array}{l}\text { ARTERIAL } \\
\text { GLUCOSE } \\
\text { LEVEL } \\
(\mathrm{mg} / \mathrm{kg})\end{array}$ & $\begin{array}{l}\text { Before } \\
\text { Alpha } \\
\text { Block } \\
\text { After } \\
\text { Alpha } \\
\text { block }\end{array}$ & $\begin{array}{l}110.5 \\
\pm 1.8 \\
110.1 \\
\pm 2.0\end{array}$ & $\begin{array}{l}112.4 \\
\pm 2.0 \\
111.6 \\
\pm 1.9\end{array}$ & $\begin{array}{l}130.7 \\
\pm 2.8 \\
\\
120.4 \\
\pm 2.3\end{array}$ & $\begin{array}{l}155.8 \\
\pm 3.2 \\
\\
134.5 \\
\pm 2.1\end{array}$ & $\begin{array}{l}150.6 \\
\pm 3.1 \\
130.6 \\
\pm 1.5\end{array}$ & $\begin{array}{l}143.4 \\
\pm 2.6 \\
\\
124.3 \\
\pm 2.4\end{array}$ & $\begin{array}{l}142.5 \\
\pm 1.9 \\
\\
121.4 \\
\pm 2.0\end{array}$ & $\begin{array}{l}138.9 \\
\pm 2.3 \\
120.6 \\
\pm 2.8\end{array}$ & $\begin{array}{l}122.0 \\
\pm 3.2 \\
\\
118.3 \\
\pm 2.7\end{array}$ & $\begin{array}{l}115.7 \\
\pm 2.5 \\
\\
117.2 \\
\pm 2.1\end{array}$ \\
\hline $\begin{array}{l}\text { VENOUS } \\
\text { GLUCOSE } \\
\text { LEVEL } \\
(\mathrm{Mg} / \mathrm{Kg})\end{array}$ & $\begin{array}{l}\text { Before } \\
\text { Alpha } \\
\text { Block } \\
\text { After } \\
\text { Alpha } \\
\text { Block. }\end{array}$ & $\begin{array}{l}107.7 \\
\pm 1.9 \\
\\
107.4 \\
\pm 2.1\end{array}$ & $\begin{array}{l}109.5 \\
\pm 2.3 \\
\\
108.8 \\
\pm 2.5\end{array}$ & $\begin{array}{l}125.2 \\
\pm 2.5 \\
\\
116.1 \\
\pm 1.9\end{array}$ & $\begin{array}{l}148.6 \\
\pm 2.6 \\
\\
129.8 \\
\pm 1.8\end{array}$ & $\begin{array}{l}146.3 \\
\pm 2.2 \\
\\
127.0 \\
\pm 2.3\end{array}$ & $\begin{array}{l}139.1 \\
\pm 2.6 \\
\\
121.3 \\
\pm 2.1\end{array}$ & $\begin{array}{l}139.2 \\
\pm 2.5 \\
\\
118.5 \\
\pm 2.7\end{array}$ & $\begin{array}{l}136.7 \\
\pm 2.0 \\
\\
118.6 \\
\pm 2.5\end{array}$ & $\begin{array}{l}120.0 \\
\pm 1.7 \\
\\
116.5 \\
\pm 1.7\end{array}$ & $\begin{array}{l}113.3 \\
\pm 1.9 \\
\\
115.5 \\
\pm 2.3\end{array}$ \\
\hline
\end{tabular}


Table 2:

EFFECT OF ADRENALINE (5mg/kg) ON ARTERIAL AND VENOUS GLUCOSE LEVELS BEFORE AND AFTER BETA ADRENERGIC RECEPTOR BLOCKADE $=5$ ( * $-\mathrm{P}<0.05,{ }^{* *}-\mathrm{P}<0.01 ;{ }^{* \star *}-\mathrm{P}<0.001$ )

\begin{tabular}{|c|c|c|c|c|c|c|c|c|c|c|c|}
\hline & & $0 . \mathrm{min}$ & $\begin{array}{l}5 \\
\text { min }\end{array}$ & $\begin{array}{l}10 \\
\min \end{array}$ & $\begin{array}{l}15 \\
\min \end{array}$ & $\begin{array}{l}20 \\
\text { min }\end{array}$ & $25 \mathrm{~min}$ & $30 \mathrm{~min}$ & $45 \mathrm{~min}$ & $60 \mathrm{~min}$ & $90 \mathrm{~min}$ \\
\hline \multirow{2}{*}{$\begin{array}{l}\text { ARTERIAL } \\
\text { GLUCOSE } \\
\text { LEVEL } \\
(\mathrm{mg} / \mathrm{kg})\end{array}$} & $\begin{array}{l}\text { Before } \\
\text { Beta } \\
\text { Block }\end{array}$ & $\begin{array}{l}110.5 \\
\pm 1.8\end{array}$ & $\begin{array}{l}112.4 \\
\pm 2.0\end{array}$ & $\begin{array}{l}130.7 \\
\pm 2.8\end{array}$ & $\begin{array}{l}155.8 \\
\pm 3.2\end{array}$ & $\begin{array}{l}150.6 \\
\pm 3.1\end{array}$ & $\begin{array}{l}143.4 \\
\pm 2.6\end{array}$ & $\begin{array}{l}142.5 \\
\pm 1.9\end{array}$ & $\begin{array}{l}138.9 \\
\pm 2.3\end{array}$ & $\begin{array}{l}122.0 \\
\pm 3.2\end{array}$ & $\begin{array}{l}115.7 \\
\pm 2.5\end{array}$ \\
\hline & $\begin{array}{l}\text { After } \\
\text { Beta } \\
\text { block }\end{array}$ & $\begin{array}{l}118.2 \\
\pm 1.9\end{array}$ & $\begin{array}{l}120.5 \\
\pm 1.7\end{array}$ & $\begin{array}{l}125.3 \\
\pm 2.1\end{array}$ & $\begin{array}{l}134.7 \\
\pm 2.0\end{array}$ & $\begin{array}{l}132.6 \\
\pm 2.8\end{array}$ & $\begin{array}{l}129.4 \\
\pm 3.1\end{array}$ & $\begin{array}{l}125.8 \\
\pm 2.4\end{array}$ & $\begin{array}{l}121.7 \\
\pm 2.7\end{array}$ & $\begin{array}{l}120.2 \\
\pm 2.1\end{array}$ & $\begin{array}{l}115.6 \\
\pm 3.0\end{array}$ \\
\hline \multirow{2}{*}{$\begin{array}{l}\text { VENOUS } \\
\text { GLUCOSE } \\
\text { LEVEL } \\
(\mathrm{Mg} / \mathrm{Kg})\end{array}$} & $\begin{array}{l}\text { Before } \\
\text { Beta } \\
\text { Block }\end{array}$ & $\begin{array}{l}107.7 \\
\pm 1.9\end{array}$ & $\begin{array}{l}109.5 \\
\pm 2.3\end{array}$ & $\begin{array}{l}125.2 \\
\pm 2.5\end{array}$ & $\begin{array}{l}148.6 \\
\pm 2.6\end{array}$ & $\begin{array}{l}146.3 \\
\pm 2.2\end{array}$ & $\begin{array}{l}139.1 \\
\pm 2.6\end{array}$ & $\begin{array}{l}139.2 \\
\pm 2.5\end{array}$ & $\begin{array}{l}136.7 \\
\pm 2.0\end{array}$ & $\begin{array}{l}120.0 \\
\pm 1.7\end{array}$ & $\begin{array}{l}113.3 \\
\pm 1.9\end{array}$ \\
\hline & $\begin{array}{l}\text { After } \\
\text { Beta } \\
\text { Block. }\end{array}$ & $\begin{array}{l}114.8 \\
\pm 2.2\end{array}$ & $\begin{array}{l}117.0 \\
\pm 2.7\end{array}$ & $\begin{array}{l}121.5 \\
\pm 2.5\end{array}$ & $\begin{array}{l}130.6 \\
\pm 1.9\end{array}$ & $\begin{array}{l}127.0 \\
\pm 2.1\end{array}$ & $\begin{array}{l}126.2 \\
\pm 2.0\end{array}$ & $\begin{array}{l}122.8 \\
\pm 2.4\end{array}$ & $\begin{array}{l}119.1 \\
\pm 2.9\end{array}$ & $\begin{array}{l}117.9 \\
\pm 2.5\end{array}$ & $\begin{array}{l}113.5 \\
\pm 2.3\end{array}$ \\
\hline
\end{tabular}

decreased from a maximum value of about $150 \%$ to a minimum level of 30 per cent.

\section{DISCUSSION}

The increases in blood flow arterial and venous

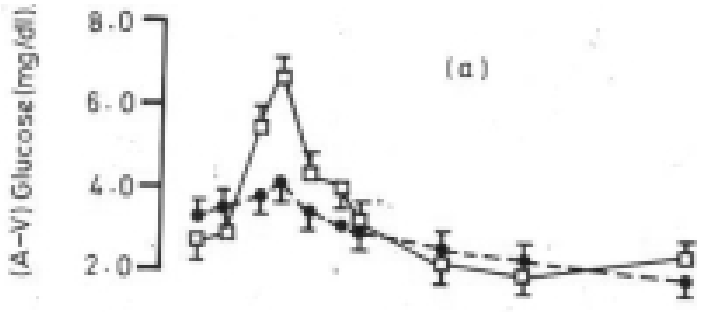
blood glucose and (A-V) glucose following adrenaline injection observed in this study is consistent with the previous observations (Gayson and Oyebola 1983; Oyebola and Durosaiye, 1988, Alada and Oyebola, 1996) in similar dog experiment.

The resting blood flow of $10.1+0.2 \mathrm{ml} / \mathrm{min}$ for the colon is similar to those reported for the upper jejunum (Grayson and Oyebola, 1983, 1985, Alada and Oyebola, 1996) and the terminal ileum (Pyebola and Durojaiye, 1988).
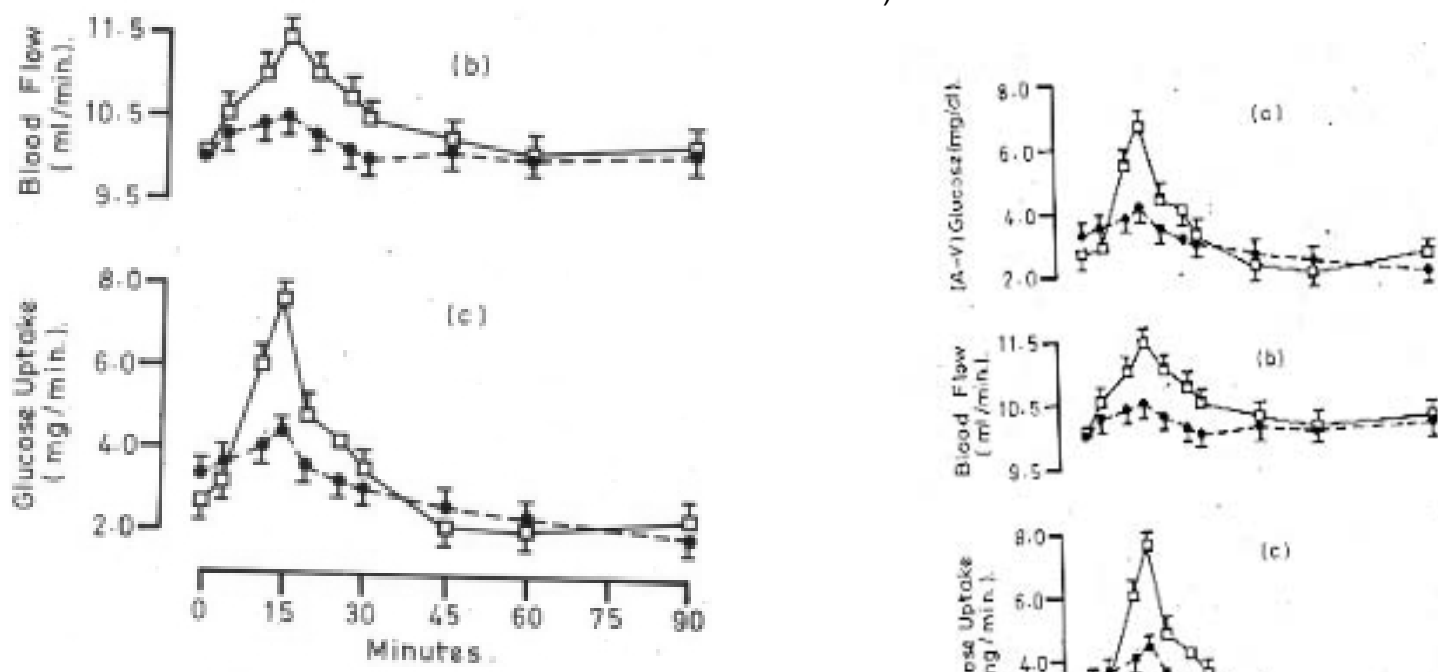

Figure 1

Effect of adrenaline on (a) (A-V) glucose (b) blood flow and (c) Glucose uptake before ( , - , ) and after (O - O) alpha blockade.

Propranolol also reduced significantly the adrenaline induced increases in (A-V) glucose and intestinal glucose uptake. The glucose uptake

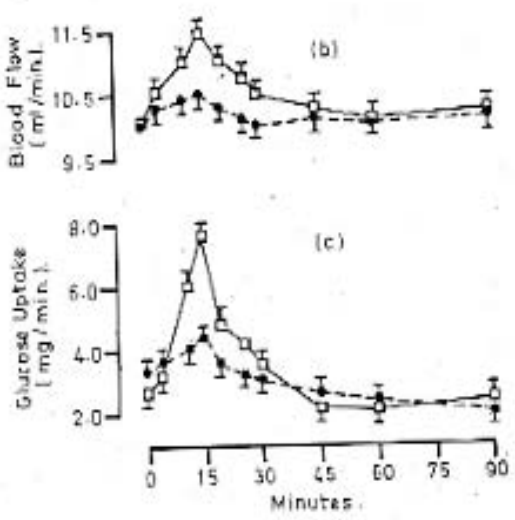

Figure 2

Effect of adrenaline on (a) (A-V) glucose (b) blood flow and (c) Glucose uptake before ( , - , ) and after $(\mathrm{O}-\mathrm{O})$ beta blockade. 
However, the average resting glucose uptake of about $28.28 \pm 1.2 \mathrm{mg} / \mathrm{min}$ by the large intestine contrasts with an average of $17.77 \pm 1.56 \mathrm{mg} / \mathrm{min}$ in the upper jejunum (Alada and Oyebola, 1996) and the terminal ileum (Oyebola and Durosaiye, 1988). The resting (AV) glucose for the large intestine was also significantly greater than that of the small intestine. This observation, therefore suggests that the large intestine at rest extracts more glucose from the blood stream than the small intestine. We have no explanation for this difference. Also, physiologic implications of this observation are at present not clear. Further studies will be required to unravel the import of this finding.

The significant increases in both the $(A-V)$ glucose and colonic glucose uptake following adrenaline injection in this study showed that the large intestine acts in a manner similar to that of the small intestine. That is, the large intestine increased its glucose uptake when the blood glucose was increased by adrenaline injection. However, while adrenaline caused an increase of about $700 \%$ in the jejunum (Grayson and Oyebola, 1983; 1985; Alada and Oyebola (1996) and about $400 \%$ in the terminal ileum (Oyebola and Durosaiye, 1988) the percentage increase in glucose uptake by the large intestine in the present study is about $150 \%$. In other words, the large intestine takes up less amount of glucose when compared with the small intestine in response to adrenaline induced hyperglycemia. If glucose uptake in the canine gut bears a direct relationship to gut metabolism, then this observation may well provide support for earlier reports (Alvarez and Starkweather, 1918; Evans, 1923; Dickens and Weilmalherbe, 1941) of a decline in the metabolic activities of gastro intestinal tract of dog from the proximal to the distal end of the tract.

The significant reduction in the colonic glucose uptake after pretreatment of the animal with prazosin or propranolol suggests the involvement of both alpha and beta adrenergic receptors in the adrenaline-induced increase in the glucose uptake by the large intestine. This observation is similar to our previous report (Alada and Oyebola, 1997) in the canine small intestine. From the present results, we conclude that the canine large bowel, like its small bowel is involved in glucose homeostasis.

\section{REFERENCES}

Alada A. R. A. and Oyebola D. D. O. (1996): Evidence that the gastrointestical tract is involved in glucose homeostasis. Afr. J. Med. And Med. Scr. 25: $243-249$.

Alada A.RA and Oyebola D. D. O. (1997): The Role of Adrenergic Receptors in the increased glucose uptake by canine gut. Afr. J. Med. \& Med. Sci. 26: $75-78$.

Alvarez V.C. and Starkweather, E. (1918): The Metabolic gradient underlying intestinal peristalsis. Amer. J. PHYSIOL> $\$^{\wedge}: 186-208$.

Evans C.L. (1923): Studies on the Physiology of Plain muscle 2. The Oxygen usage of plain muscle and its relation to tonus. J. PHYSIOL. (London) 56: $23-32$.

Dickens. F. and Weil Malherbe, H. (1914): Metabolism of normal and tumor tissue la. The metabolism of $\mathrm{B}$ intestinal mucus membrane. Biochem J. 35: 7 - 15.

Durotoye A.O. and Grayson J. (1971): Heat production in the gastro-intestinal tract of the dog. J. Physiol 214: $417-426$.

Grayson J. and Oyebola D. D. O. (1983): The effect of catecholamines on intestinal glucose and oxygen uptake in dog. J. Physiol (Lond.) 343: 311-322.

Grayson J. and Oyebola D. D. O. (1985): Effect of nicotine on blood flow, oxygen consumption and glucose uptake in the canine small intestine. Br. J. Pharmacol 85: $797-804$.

Oyebola D. D. O. and Durosaiye, G.O (1981): Effect of adrenaline and propranolol on glucose uptake in the canine terminal ileum Nig. J. of Physiol. Sci. 4: 31 - 37.

Trinder P. (1969): Determination of blood glucose using 4amino-phenazone as oxygen acceptor J. Chin. Path. 22: 246 248.

Received: February 2001

Accepted in final form: June 2001 